\title{
Enclaves in tourism: Producing and governing exclusive spaces for tourism
}

\section{Introduction}

Exclusively planned tourism destinations and resorts have increased substantially over the last few decades. These tourism spaces include different forms and kinds of tourism environments, such as all-inclusive resorts, gated resort communities, private cruise linerowned islands, and privatized beaches, for example. In research, exclusively planned destinations and tourism environments are usually termed tourism enclaves, representing outcomes of a non-locally driven and governed neoliberal market economy (Britton, 1991; Brohman, 1996; Shaw \& Shaw, 1999). However, while being externally driven they are strongly based on certain kinds of local planning and governance modes of the tourism industry and local and regional development.

In general, tourism enclaves contain all or a vast majority of the facilities, operations, and services needed for tourists and their enjoyment. At the same time, locals' access to enclaves may be controlled or even prevented, and can be limited to working purposes only. Nowadays, enclaves and enclavic processes separating tourism and tourists from local realities are relatively visible elements of tourism, especially in planning and development contexts dominated by external forces and actors (see Buzinde \& Manuel-Navarrete, 2013; Saarinen, 2017; Torres \& Momsen, 2005). This has led to an increasing scholarly and public interest in enclave tourism, as such forms and environments of tourism often include power inequalities and unsustainable practices that can have serious negative impacts and trade-offs for local social and economic processes (see Saarinen, Rogerson, \& Hall, 2017). In global development discussions, these negative impacts and trade-offs can hinder the possibilities to use the tourism industry as a vehicle for development and a contributor to poverty alleviation, for example, in the context of the United Nations Sustainable Development Goals (SDGs) of the 2030 Agenda for Sustainable Development (United Nations, 2015).

Despite its locally problematic nature, however, enclave tourism seems to have many desirable characteristics for the global tourism industry and for organizing the value-chain optimally for revenue creation with minimal spillover, especially in foreign operational environments. Enclavic environments also seem to suit tourists, as many (and an increasing 
number) do enjoy being mass tourists in all-inclusive resorts (see Anderson, Juaneda, \& Sastre, 2009; Butler, 1990, 1999; Wong \& Kwong, 2004). In addition, recent debates in relation to uncontrolled tourism development in a form of so-called overtourism (see Milano, Novelli, \& Cheer, 2019) indicate that some local residents may prefer a clearer distinction between spaces for tourists and local spaces, especially in urban residential contexts. All this makes enclave tourism a timely and highly relevant topic for research and tourism planning and governance.

This special issue takes an overview of research on tourism enclaves and aims to contribute to our understanding of how these exclusive tourism spaces are created and transformed and how they (dis)connect with local realities and shape places. In addition to theoretical understanding, the key issues relate to the implications of enclave tourism for local and regional development and their governance. After an overview of enclave tourism and related concepts and perspectives in research, the paper introduces the themes developed in this special issue by its contributing authors. Finally, future research needs are briefly discussed.

\section{Tourism enclaves}

There are different terms and definitions used for tourism enclaves and the enclavization process on a destination scale. Related terms include concepts such as the environmental bubble (Cohen, 1972) or tourist bubble (Judd, 1999) and total institutions (Dann, 2000). Regardless of the chosen term, there are two common elements in their use and definitions. First, different terms referring to enclave tourism development include a general idea that these kinds of tourism spaces are somehow separated from their surrounding environment: enclaves are based on "a well-defined perimeter [that] separates the tourism space" (Judd, 1999, p. 16), i.e. they are "isolated and separated from wider society" (Weaver, 2005, p. 168).

Secondly, their development, governance and existence are often externally driven, but take place and are processed on different scales at the same time. Shaw and Shaw (1999) indicate this non-local and multiscale nature of tourism enclaves in their definition, stating that "enclaves are operated by global capital and transnational organizations through a series of spatial networks, which unless they are strongly regulated by the local state, allow only limited economic benefits to accrue to the host communities" (Shaw \& Shaw, 1999, p. 68). Enclavization can also be seen as a transformation process in which a destination evolves 
simultaneously toward socio-spatial homogenization and differentiation. This means that while destinations grow and transform toward similarity, resembling other large-scale resorts typical of the global tourism industry, and their original character is being eroded away in a Relphian (1976) manner (see Wall-Reinius, Ioannides \& Zampoukos, 2019 in this special issue), they are also undergoing differentiation and being separated from their surrounding socio-economic structures and characteristics (Cohen, 2006; Saarinen, 2004, see also MacCannell, 1976: 44-8).

From a geopolitical perspective, the process of separating enclaves from their surrounding socio-cultural environments and regional economies can be understood as a form of human territoriality. For Sack (1986), human territoriality is a form of control that involves organizing space and creating boundaries that serve to facilitate that organization. In this respect, tourism enclaves are products of border-making between "us and them" (hosts and guests), making enclaves exclusive spaces and spaces of exclusion at the same time. On the one hand, as noted above, this means that tourism enclaves contain all or most of the facilities, services, and activities needed for visitors to enjoy their holiday in a destination (Saarinen, 2017). On the other hand, locals' access to enclavic tourism spaces is often regulated (Carlisle \& Jones, 2012) with limited possibilities to benefit from tourism in terms of income and employment. As noted by Butler (1990, p. 41):

"It is possible to almost completely avoid contact between tourists and locals [...]. Tourist enclaves can be staffed by imported labor and tourists encouraged not to venture out of the enclave, as, for example, in many casinos or Club Med-type resorts."

Thus, tourism enclaves can involve injustices and power inequalities in labor relations in a form of so-called social dumping, in which multinational companies originating from "high wage" countries search for ways to avoid legal constraints and introduce social dumping at lower levels of the production chain elsewhere or on site by using migrant workers (Terry, 2009; Ioannides \& Zampoukos, 2018). Therefore, it is not surprising that many authors perceive tourism enclaves as an antithesis to sustainable development and sustainable tourism (Farmaki et al., 2017) or inclusive growth (see Scheyvens \& Biddulph, 2018). From this perspective, research has characterized enclavic spaces as international mass tourism destinations dominated and/or operated by global capital and actors providing limited benefits and participation for local communities. Thus, tourism enclaves are seen as spaces providing 
minimal opportunities for host-guest interaction, which widens the gap between host communities and visitors (Prayag, 2015). Enclavic tourism spaces are also regarded as having weak linkages with the surrounding regional economy, a situation that often leads to high economic leakages and low levels of local employment and salaries (see Mbaiwa, 2005).

\section{Studies on enclave tourism}

Although interest in enclave tourism has increased in the past decade, the phenomenon itself has a relatively long history in tourism development and related studies. In the 1960s, Knebel (1960) discussed attraction sites that were characterized by tourists' "own inner world" (Eigenwelt). In the 1970s, MacCannell (1973) conceptualized staged authenticity, in which host populations and/or the tourism industry constructed a front and back stage separating local realities and touristic experience needs and activity settings (see also MacCannell, 1976).

The early studies in particular focused on mapping and characterizing the tourism enclaves and the nature of connections or lack of them between the hosts and guests (Cohen, 1972, 2006; Judd, 1999). Tourism enclaves were seen as physically and mentally bounded spaces from local realities (see Lew, 2004). On the one hand, these borders - visible or mental were porous, allowing some interaction and mobility. On the other hand, however, this interaction and mobility was often seen as one-dimensional and driven by the enclaves, the tourism industry and its needs (Edensor, 1998). This unbalanced nature of interaction was understood to be a result of the uneven power relations between the industry and local communities and actors. In the 1980s, Britton (1982), for example, critically analyzed how economically and politically powerful tourist-generating regions reorganize destination spaces by regulating and controlling tourist expenditure through limiting their mobility and excluding local producers and other local service providers from the tourism value-chain (see Shaw \& Shaw, 1999).

Theoretically, the research on uneven tourism development was largely based on a dependency theory, indicating that underdevelopment is mainly a result of the geographically, socio-economically, and politically peripheral position of destination countries and regions in the world economy. For example, tourism development on islands has often been "characterized by a condition of dependency" in research (Nunkoo \& Ramkissoon, 2016, p. 
557). From this dependency perspective, tourism enclaves are seen as products of global capitalism (see Brohman, 1996) with vocal calls to recognize "the capitalistic nature" of tourism (Britton, 1991, p. 453). Indeed, the deepening forces of globalization, with the relatively free movement of capital and (privileged) people, have resulted in an increasing number and variety of tourism enclaves in recent decades. This critical structuralist approach paved the way to political economy and political ecology approaches in tourism development studies (see Bianchi, 2009; Mosedale, 2011; Nepal \& Saarinen, 2016) that have conceptualized tourism destinations and enclaves as transnational spaces operating in a multiscalar way (see Rogerson, 1990). Torres and Momsen (2005), for example, indicated in their study that locals call Cancun in Mexico "Gringolandia," reflecting the non-local character, dominance, and governance of the destination.

Recent research has emphasized that although tourism enclaves are based on a bordering process separating the social realities of hosts and guests (Dürr, 2012), the enclaves can also be "dynamic places of negotiation, exchange, and collaboration across cultures, nationalities and classes" (Manuel-Navarrete, 2016, p. 507). From this perspective, tourism enclaves provide meeting points for the industry, local developers, and labor. These relations, however, are still often seen as being based on an uneven exchange between the tourism industry actors and communities (see Saarinen, 2017; Torres \& Momsen, 2005). Timely research examples include modern slavery, in which the links between the global tourism industry's supply chains and human rights abuses in sex tourism, labor rights, and social dumping (e.g. the use of cheap migrant labor), for example, are analyzed (Cheer, 2018). Modern day slavery involves practices, processes, and institutions that undermine or restrict human freedoms, and at the same time it exploits people through illegal and/or legal ways (see van Anker, 2004; Cheer, 2018), in which the bordering processes of tourism enclaves may play a critical role by enforcing injustices. Thus, while the borders of enclavic spaces may be conceptualized in research as permeable, negotiable, and challenged in local everyday life, the bordering process itself is often characteristically based on reinforced inequalities by the tourism enclaves and the global industry operating at different scales.

\section{Insights from the special issue}

Given the significance of borders and border-making in enclave tourism, we start this special issue with dell'Agnese's contribution. Dell'Agnese discusses the duality of borders in a 
Maldivian resort, where the external border regulates the movements of tourists and locals, and the inner border segregates frontline staff and other workers, usually of other origin and who are restricted in their movement. Dell'Agnese concludes that the outer/external borders are becoming more porous, whereas others remain difficult to cross.

Another significant parameter of enclave tourism is its standardized scope. The framework in Wall-Reinius, Ioannides, and Zampoukos's article is based on the idea of placelessness by Relph (1976). By investigating the marketing of all-inclusive tourism, they conclude that allinclusive holiday resorts, through their scale, design, and function, purposefully separate themselves from their immediate surroundings. In addition, Wall-Reinius et al. further state that there seems to be a genuine lack of interest by tour operators to encourage visitors to areas and/or attractions outside the core resort structures. The authors conclude that the allinclusive resorts pay relatively little attention to place-based attributes, representing decontextualized and interchangeable spaces. Based on their analysis the authors also suggest a typology of enclavism.

Weaver also focuses on the marketing of enclaves with a focus on the selling of seagoing tourism bubbles. In his article, Weaver highlights the co-existence of desirable aspects of cruise ships and problems that passengers encounter, such as seasickness, boredom, and discomfort. Weaver concludes his analysis based on guidebooks, magazines, and trade journals by presenting a future research agenda. He suggests that future research on enclave tourism should focus on employees and their experiences of enclosure; a deeper exploration of emotions in relation to tourist bubbles; and contemporary consumer culture and commercial structures that support and influence individual consumers. Related to the last point, comparisons between shopping on cruise ships and in malls could be fruitful research tasks.

In their study, Paananen and Minoia investigate cruise passengers leaving the controlled environment by analyzing the movements of cruise tourists in the city of Helsinki during their short visit. The authors focus on enabling and disenabling aspects of mobility among cruise passengers who choose to move independently around the city. Paananen and Minoia discuss social interaction among the travel parties, traffic culture, sense of direction, and time-related anxiety, as well as the use of wayfinding tools, such as street signs, mobile devices, and physical maps. The authors suggest that the used "go-along" research method offers a 
dynamic mode for observing short-term tourism, which can be useful for urban planning in tourist cities and particularly in destinations with a growing number of tourists causing disturbances and residential issues and conflicts.

Ioannides, Röslmaier, and van der Zee's article relates to the sharing economy with an example on Airbnb activities and their spatial tendencies in the Dutch city of Utrecht. According to their study, Airbnb-based economy and activities are growing in the city, and they cluster particularly in the city center and immediate surroundings of the main tourism attractions, restaurants, and other accommodation facilities (i.e. hotels). Ioannides et al. conclude that Airbnb activities take on the role as an instigator of urban tourism bubble expansion, which contributes to a gradual touristification of the urban structure, especially of the city center. According to them, future research should analyze the effects of Airbnb on housing markets, the hotel industry, social dimensions of neighborhoods, and the implications of an exodus of long-term residents as more properties transform into Airbnb units.

Based on earlier research and literature, Ek and Tesfahuney outline a conceptual article highlighting understandings of the phenomenon of tourism enclaves. They claim that tourism enclaves have mostly been understood as geographically distinct (i.e. bounded) areas. In contrast to this topographical understanding, the authors suggest topological understandings to offer more complex and nuanced conceptualizations of tourism enclaves. Based on a politicophilosophical framework and relational ontology, Ek and Tesfahuney outline ideas for future directions for research on tourism enclaves, which highlight the relational notion of space, its functionality, connections, and interactions.

The final article of this special issue deals with images selling Andalusia, Spain, to the British market. According to García Martín, Villar Lama, and Cruz Mazo, the rapid emergence of coastal resorts along the Mediterranean fringe has resulted in socio-spatial structures resembling "mini colonies," in which tourists are detached from the local physical and cultural environments. At the same time, this disconnectedness encourages a sense of belonging to their own expatriate nationality. García Martín et al. focus on the importance of elements and features in social imaginaries and discourses around Andalusia as a destination and how it is constructed in real estate websites targeting British markets. The authors conclude that the romantic projection of the image of Andalusia (i.e., its sublime, picturesque, 
and exotic nature) still persists, whereas other landscape qualities and settings seem to receive less visibility.

\section{Future research needs}

Enclave tourism has been criticized for its socio-economic, political, and environmental impacts and injustices. Enclaves are separated from their surrounding socio-spatial structures in different ways and on various levels, but they are not isolated from the forces and processes of globalization. Indeed, tourism enclaves are simultaneously spaces of enclosure and connections, and future research on enclaves should focus on the intertwined linkages and flows of workers, goods, ideas, capital, and so on, on different scales. Analysis of this enclosure - connection incongruity would create a better understanding of those driving forces, processes, and networks that lead development toward enclavic spaces on a local scale. In this respect, connections to border studies and geopolitical research would be beneficial. Fregonese and Ramadan (2015), for example, have conceptualized hotels, with their selective openness and closedness to their surroundings, as geopolitical spaces and sites.

Obviously, tourism enclaves are not totally separated from their environs. Thus, it is important to analyze in which ways the enclavic spaces interface with their surrounding communities and societies, and how benefits and costs are distributed. More research is needed on local people and their (lack of) opportunities to access certain locations, the labor market, housing, and services. Enclaves can also have impacts on wider real estate and land markets and developments. Related to this, it is important to analyze destination development policies, planning, and governance strategies and practices. In particular, local participation and stakeholder roles in policymaking and planning still remain an overlooked research topic. In addition, there may also be some positive planning and policy aspects related to tourism bubbles. From this perspective, the question is whether a clearer distinction between spaces for tourists and locals or other modes of regulations would serve a purpose in some tourism development contexts, such as conflict situations between residents and uncontrolled tourism growth. This is a relevant topic for researchers, planners and tourism developers in overtourism situations.

Enclave tourism has been associated with a range of socio-economic and cultural issues, but it may also have serious environmental consequences. These negative environmental impacts 
associated with enclavic tourism development can hinder the industry's capacity to act in responsible and sustainable ways, especially in peripheral areas and the Global South. Thus, there is a need for research on overconsumption, waste management, and water consumption, for example, and we suggest that future studies should highlight the consumptive aspects of enclaves and environmental pressures created by enclave tourism developments.

Tourism is a land use form and increasingly so. However, gated communities and enclavic resorts do not only occupy land; they create socio-spatial patterns of inclusions and exclusions. Thus, as manifestations of territorialization and privatization, enclaves can have serious consequences for locals' access to vital resources, such as land and clean water (see Cole \& Browne, 2015). Therefore, studies on resource access and land grabbing, for example, are highly needed as they would create critical knowledge of the socio-economic, political, and spatial impacts of enclavic spaces. In this respect, the question of land grabs may have commonalities with enclosures and the enclavization process, as they are the antithesis to commons, common land and common-pool resources. In this context, future research should focus more on social and environmental justice, including resource access, equity, and the consequences of land use in tourism.

\section{References}

Anderson, W., Juaneda, C., \& Sastre, F. (2009). Influences of pro- all-inclusive travel decisions. Tourism Review, 64, 4-18. doi: 10.1108/16605370910963482

Bianchi, R. (2009). The 'critical tourism' in tourism studies. A radical critique. Tourism Geographies, 11, 484-504. doi:10.1080/14616680903262653

Britton, S. G. (1982). The political economy of tourism in the Third World. Annals of Tourism Research, 9, 331-358. doi:10.1016/0160-7383(82)90018-4

Britton, S. (1991). Tourism, Capital, and Place: Towards a Critical Geography of Tourism. Environment and Planning D: Society and Space, 9, 451-478. doi:10.1068/d09045

Brohman, J. (1996). New directions in tourism for third world development. Annals of Tourism Research, 23, 48-70. doi:10.1016/0160-7383(95)00043-7

Butler, R. (1990). Alternative tourism: Pious hope or Trojan Horse? Journal of Travel Research, 28, 40-45.

Butler, R. (1999). Sustainable tourism: a state-of-the-art review. Tourism Geographies, 1, 725. 
Buzinde, C .N. \& Manuel-Navarrete, D. (2013). The social production of space in Tourism enclaves: Mayan children's perceptions of tourism boundaries. Annals of Tourism Research, 43, 482-505. doi.org/10.1016/j.annals.2013.06.003

Cole, S. \& Browne, M. (2015). Tourism and Water Inequity in Bali: A Social-Ecological Systems Analysis. Human Ecology, 15, 439-450.

Cohen, E. (2006). Pai - A backpacker enclave in transition. Tourism Recreation Research, 31 , 11-27. doi:10.1080/02508281.2006.11081502

Carlisle, S. \& Jones, E. (2012). The Beach Enclave: A Landscape of Power. Tourism Management Perspectives, 1, 9-16.

Cheer, J.M. (2018). Geographies of marginalization: encountering modern slavery in tourism. Tourism Geographies, 20, 728-732.

Cohen, E. (1972). Rethinking the sociology of tourism. Annals of Tourism Research, 6, 1835.

Dann, G. (2000). Overseas holiday hotels for the elderly: Total bliss or total institution?. In Robinson, M., Long, P., Evans, N., Sharpley, R. \& J. Swarbrooke (Eds.), Reflections on international tourism: Motivations, behaviour and tourist types, pp. 83-94. Sunderland: The Centre for Travel \& Tourism.

Dürr, E. (2012). Encounters over garbage: tourists and lifestyle migrants in Mexico. Tourism Geographies, 12, 339-355. doi: 10.1080/14616688.2012.633217

Edensor, T. (1998). Tourists at the Taj. Performance and meaning at a symbolic site. London and New York, NY: Routledge.

Farmaki, A., Georgiou, M. \& Christou, P. (2017). Growth and impacts of all-inclusive holiday packages: echoed form the industry. Tourism Planning \& Development, 14, 483502.

Fregonese, S, \& Ramadan, A. (2015). Hotel geopolitics: A research agenda. Geopolitics, 20, $793-813$.

Ioannides, D. \& Zampoukos, K. (2019). Tourism's labour geographies: Bringing tourism into work and work into tourism. Tourism Geographies, 20, 1-10, doi:

$10.1080 / 14616688.2017 .1409261$

Judd, D. (1999). Constructing the tourist bubble. In D. Judd \& S. Fainstein (Eds.). The tourist city, pp. 35-53. New Haven: Yale University Press.

Knebel, H-J. (1960). Soziologische strukturwandlungen im modernen tourismus [Sociological structural changes in modern tourism]. Stuttgart: Enke Knoblich.

Lew, A. (2004). Editorial: Tourism enclaves in place and mind. Tourism Geographies, 6, 1. 
MacCannell, D. (1973). Staged Authenticity: Arrangements of Social Space in Tourist Settings. American Journal of Sociology, 79(3), 589-603.

MacCannell, D. (1976). The tourist. A new theory of the leisure class. New York, NY: Schoken Books.

Mbaiwa, J. E. (2005). Enclave tourism and its socio-economic impacts in the Okavango Delta, Botswana. Tourism Management, 26, 157-172.

Manuel-Navarrete, D. (2016). Boundary-work and sustainability in tourism enclaves. Journal of Sustainable Tourism, 24(4), 507-526.

Milano, C., Novelli, M. \& Cheer, J.M. (2019). Overtourism and Tourismphobia: A Journey Through Four Decades of Tourism Development, Planning and Local Concerns. Tourism Planning \& Development. Doi: 10.1080/21568316.2019.1599604

Mosedale, J. (Ed.)(2011). The political economy of tourism: A critical perspective. London and New York: Routledge.

Nepal J. \& Saarinen, J. (Eds.)(2016). Political ecology and tourism. London: Routledge.

Nunkoo, R. \& Ramkissoon, H. (2016). Stakeholders' views of enclave tourism: A grounded theory approach. Journal of Hospitality \& Tourism Research, 40, 557-588.

Prayag, G. (2015). Beyond enclave tourism: the road to sustainability. In N. Morpeth \& H. Yan (eds.), Planning for tourism: towards a sustainable future, pp. 240-258. Oxfordshire: CABI.

Relph, E. (1976). Place and placelessness. London: Pion.

Rogerson, C. M. (1990). Sun international: The making of a South African tourismus multinational. Geo Journal, 22, 345-354. doi:10.1007/BF00192834

Saarinen, J. (2004). 'Destinations in change': The transformation process of tourist destinations. Tourist Studies, 4, 161-179.

Saarinen, J. (2017). Enclavic tourism spaces: Territorialization and bordering in tourism destination development and planning. Tourism Geographies, 19, 425-437.

Saarinen, J., Rogerson, C. \& C. M. Hall (2017). Geographies of Tourism Development and Planning. Tourism Geographies, 19, 307-317.

Sack, R. (1986). Human territoriality: its theory and history. Cambridge: Cambridge University Press.

Scheyvens, R. \& Biddulph, R. (2018). Inclusive tourism development. Tourism Geographies, 20, 589-609. doi: 10.1080/14616688.2017.1381985

Shaw, B. J., \& Shaw, G. (1999). 'Sun, sand and sales': Enclave tourism and local entrepreneurship in Indonesia. Current Issues in Tourism, 2, 68-81. 
Terry, W. (2009). Working on the Water: On Legal Space and Seafarer Protection in the Cruise Industry. Economic Geography, 85, 463-482. doi: 10.1111/j.19448287.2009.01045.x

Torres, R. \& Momsen, J. (2005). Gringolandia: The Construction of a New Tourist Space in Mexico. Annals of the Association of American Geographers, 95, 314-335. doi.org/10.1111/j.1467-8306.2005.00462.x

United Nations. (2015). Transforming our world: the 2030 Agenda for Sustainable Development. Resolution adopted by the General Assembly on 25 September 2015. United Nations: New York.

Van Anker, C. (Ed.)(2004). The political economy of new slavery. New York: Palgrave.

Wall-Reinius, S., Ioannides, D. \& Zampoukos, K. (2019). Does Geography Matter in AllInclusive Resort Tourism? An investigation of the marketing approach of major Scandinavian Tour operators. Tourism Geographies. doi: $10.1080 / 14616688.2017 .1375975$

Weaver, A. (2005). Spaces of containment and revenue capture: 'Super-sized' cruise ships as mobile tourism enclaves. Tourism Geographies, 7, 165-184.

Wong, C., \& Kwong, W. (2004). Outbound tourists' selection criteria for choosing allinclusive package tours. Tourism Management, 25, 581-592. doi: 10.1016/j.tourman.2003.06.002 